\title{
Simple and Rapid Determination of Boron in the Wastewater with Azomethine $H$ Using Accelerating Effect of Ammonium Ion
}

\author{
Masatoshi ENDO*, Eishi YOSHIKAWA*, Satomi NEMOTO*, Yu TAKAHASHI*, \\ Kiyofumi SAKAI*, Hitoshi MIZUGUCHI*, Atsushi SASAKI**, Kenichi SUGAWARA***, \\ Koichi SATO***, Tadao IHARA*** \\ *Graduate School of Science and Engineering, Yamagata University, 4-3-16 Jhonan, \\ Yonezawa, Yamagata 992-8510, Japan \\ **Technical Division of Instrumental Analysis, Faculty of Engineering, Yamagata University, \\ 4-3-16 Jhonan, Yonezawa, Yamagata 992-8510, Japan \\ ***Toho Technos Co., Ltd., 7-64 Tsurugasawa, Takizawa, Ichinoseki, Iwate 029-0132, Japan
}

\begin{abstract}
Boron is widely used in industry, and is regulated by the effluent standard $(10 \mathrm{mg} / \mathrm{L})$ in Japan. The standard azomethine $\mathrm{H}$ absorptiometric method for determining boron concentration requires long time; therefore, we have developed a simple, rapid azomethine $\mathrm{H}$ method for the management of the wastewater treatment equipment. The amount of boron was determined by measuring the absorbance of the boron-azomethine $\mathrm{H}$ complex after 5 min by using a simple spectrophotometer with a photodiode $(370-600 \mathrm{~nm})$ and a light-emitting diode $(470 \mathrm{~nm})$. Phosphate buffer with ammonium chloride was used, because the ammonium salt accelerated the formation of the boron complex. The effect of a large amount of calcium ions in the wastewater, which originated from calcium hydroxide, was eliminated by adding an excess of the buffer reagents. A combination of powdered azomethine $\mathrm{H}$, L-ascorbic acid, EDTA, potassium dihydrogenphosphate, disodium hydrogenphosphate, and ammonium chloride was appropriate for the simple, rapid on-site determination of boron using a portable spectrophotometer.
\end{abstract}

Keywords: accelerating effect, ammonium salt, azomethine $H$, boron determination

\section{INTRODUCTION}

Boron is a naturally occurring element found in the form of borates, and is found in seawater, sedimentary rocks, coal, shale, and some soils. The high concentration of boron in seawater $(4.5 \mathrm{mg} / \mathrm{L})$ means that marine clays are rich in boron relative to other rocks (Howe, 1998). Although boron is an essential micronutrient for plants, the difference between deficient and toxic concentrations is smaller for boron than for any other nutrient element. Plants respond directly to the activity of boron in soil solution, but only indirectly to boron adsorbed on soil constituents (Goldberg, 1997). The highest naturally occurring concentrations of soil boron are in soils derived from marine evaporites and marine argillaceous sediment. The most important source is irrigation water, but other sources include surface mining waste, fly ash, and industrial chemicals (Nable et al., 1997). Boron and boron compounds are widely used in industry, and the production of boron compounds has increased because of the demand for these compounds in nuclear technology, refractory materials, heat-resistant ceramics, high quality steel, heat-resistant polymers, and catalysts (Morales et al., 2000). Therefore, industrial wastewater with a high boron concentration is increasingly being discharged. High levels of boron are toxic to humans and hamper seed development.

The environmental quality standard for boron has been set at $1 \mathrm{mg} / \mathrm{L}$ in Japan. The

Address correspondence to Masatoshi Endo, Graduate School of Science and Engineering, Yamagata

University, Email: endomasa@yz.yamagata-u.ac.jp

Received May 10, 2012, Accepted March 22, 2013. 
effluent standard is $10 \mathrm{mg} / \mathrm{L}$ for water for public use, rivers, lakes, and marshes, and 230 $\mathrm{mg} / \mathrm{L}$ for the sea. The preliminary effluent standard for the hot spring industry and the galvanizing industry is $500 \mathrm{mg} / \mathrm{L}$ and $50 \mathrm{mg} / \mathrm{L}$, respectively. Because boron is an essential element for plants and animals, its analysis in food and seed is also important. The boron determination methods stated in JIS K0102 are the azomethine $\mathrm{H}$ (1-(salicylideneamino)-8-hydroxynaphthalene-3,6-disulphonic acid) method, the methylene blue method, the curcumin method, and inductively coupled plasma atomic emission spectroscopy (ICP-AES). The methylene blue method requires the preparation of many synthetic solutions (Cizek and Studlarova, 1984), sulfuric acid is used in the curcumin method (Liu and Lee, 2009), and the on-site measurement of boron is difficult with ICP-AES and/or ICP-MS. The azomethine $\mathrm{H}$ method depends on the spectrophotometric measurement of the boron-azomethine $\mathrm{H}$ complex, and is appropriate for on-site analysis. The boron determination range with the azomethine $\mathrm{H}$ method is 0.2 to $1 \mathrm{mg} / \mathrm{L}$. Azomethine $\mathrm{H}$ was first proposed in 1961 as a reagent for boron determination (Capelle, 1961). There are a lot of literatures of the azomethine $\mathrm{H}$ method (Takeuchi and Takeyama, 1983; Hosoya and Takeuchi, 1986; Ozawa, 1986), and azomethine HR (1-(2,4-dihydroxybenzylidene-amino)-8-hydroxynaphthalene-3,6disulphonic acid) was suggested in 1989 by Zenki et al. (1989) as a new reagent for boron determination, but reaction mechanism for the boron-azomethine $\mathrm{H}$ complex was not introduced. In aqueous solution, most of the azomethine $\mathrm{H}$ is hydrolyzed to salicylaldehyde and $\mathrm{H}$-acid; therefore, the formation of the boron-azomethine $\mathrm{H}$ complex is very slow, which means the azomethine $\mathrm{H}$ method is also slow. Recently, Matsuo et al. confirmed that salicylaldehyde react with $\mathrm{H}$-acid to form azomethine $\mathrm{H}$ by NMR, but the intermediate and acceleration of formation of the boron-azomethine complex were not investigated (Matsuo et al., 2004). For boron removal, calcium hydroxide and aluminum sulfate is used in the coagulation-sedimentation method. Therefore calcium ions were included in the wastewater. Azomethine $\mathrm{H}$ method is used for determination of boron in treated wastewater (Kluczka et al., 2007). So, effect of coexisting ions to determination of boron by azomethine $\mathrm{H}$ method was also studied.

In this paper, the reaction mechanism and acceleration effect for the boron-azomethine $\mathrm{H}$ method were discussed, and a simple, rapid azomethine $\mathrm{H}$ method for analyzing boron in wastewater using a portable spectrophotometer was studied.

\section{MATERIALS AND METHODS}

\section{Reagents}

A $1.0 \times 10^{-2} \mathrm{~mol} / \mathrm{L}$ azomethine $\mathrm{H}$ solution was prepared by dissolving azomethine $\mathrm{H}$ (0.467 g; Dojindo Molecular Technologies, Inc.) and EDTA (0.372 g; Dojindo Molecular Technologies, Inc.) in a $1.0 \times 10^{-2} \mathrm{~mol} / \mathrm{L}$ ascorbic acid solution $(100 \mathrm{~mL})$. A $0.1 \mathrm{~mol} / \mathrm{L}$ boron standard solution was prepared by dissolving boric acid $(0.618 \mathrm{~g}$; Kanto Chemical Co., Inc.) in doubly deionized water $(100 \mathrm{~mL}) .100 \mathrm{mg} / \mathrm{L}$ boron standard solution was prepared by dissolving boric acid ( $0.057 \mathrm{~g}$; Kanto Chemical Co., Inc.) in doubly deionized water $(100 \mathrm{~mL})$. Phosphate buffer solution was prepared by dissolving potassium dihydrogenphosphate $(13.6 \mathrm{~g})$ and disodium hydrogenphosphate $(14.2 \mathrm{~g})$ in doubly deionized water $(100 \mathrm{~mL})$. Acetate buffer solution was prepared by mixing a $7 \mathrm{~mol} / \mathrm{L}$ ammonium acetate solution and a $17 \mathrm{~mol} / \mathrm{L}$ acetate solution. Phthalate buffer solution was prepared by mixing a $0.1 \mathrm{~mol} / \mathrm{L}$ sodium hydroxide solution $(33 \mathrm{~mL})$ 
and a $0.1 \mathrm{~mol} / \mathrm{L}$ potassium hydrogen phthalate solution $(20 \mathrm{~mL})$. MES buffer solution was prepared by mixing a $0.1 \mathrm{~mol} / \mathrm{L}$ sodium hydroxide solution $(25 \mathrm{~mL})$ and a 0.1 $\mathrm{mol} / \mathrm{L} 2$-morpholinoethanesulfonic acid solution $(10 \mathrm{~mL})$.

\section{Real sample}

Real samples (A, B, C and D) including boron were collected from hot spring waters at four hot spring facilities in Yamagata prefecture, Japan. Real wastewater sample (E) including boron was collected from hot spring wastewaters at hot spring facility in Ibaraki prefecture, and real wastewater samples ( $F$ and $G$ ) were provided from an optical glass company in Fukushima prefecture.

\section{Procedure}

\section{(1) Improved azomethine H method (Method 1)}

The $0.1 \mathrm{~mol} / \mathrm{L}$ boron standard solution was transferred into a $25 \mathrm{~mL}$ polyethylene measuring flask, and the $1.0 \times 10^{-2} \mathrm{~mol} / \mathrm{L}$ azomethine $\mathrm{H}$ solution $(12.5 \mathrm{~mL})$, phosphate buffer solution $(2 \mathrm{~mL})$, and an appropriate quantity of an additive (ammonium acetate, methylamine hydrochloride, dimethylamine hydrochloride, trimethylamine hydrochloride, tetramethylammonium chloride, 4-methylpyridine, pyridine, or ammonium chloride) were added successively. The solution was diluted to the mark with doubly deionized water, mixed well, and allowed to stand for $15 \mathrm{~min}$. The absorbance at $413 \mathrm{~nm}$ was measured in a $1 \mathrm{~cm}$ cell against the reagent blank with a spectrophotometer (Hitachi, U-3000).

(2) Using powdered reagents for the improved azomethine $H$ method with conventional spectrophotometer (Method 2)

Azomethine H $(0.058 \mathrm{~g})$, L-ascorbic acid (0.022 g), EDTA (0.047 g), potassium dihydrogenphosphate $(0.272 \mathrm{~g})$, disodium hydrogenphosphate $(0.071 \mathrm{~g})$, and ammonium chloride $(0.669 \mathrm{~g})$ were dissolved in $100 \mathrm{mg} / \mathrm{L}$ boron standard solution $(0.2$ $\mathrm{mL}$ ). The volume of the solution was made up to $25 \mathrm{~mL}$ with doubly deionized water, and allowed to stand for $15 \mathrm{~min}$. The absorbance at $413 \mathrm{~nm}$ was measured in a $1 \mathrm{~cm}$ cell against the reagent blank.

(3) Using powdered reagents for the improved azomethine $H$ method with portable spectrophotometer (Method 3)

Azomethine H (0.012 g), L-ascorbic acid (0.004 g), EDTA (0.009 g), potassium dihydrogenphosphate $(0.054 \mathrm{~g})$, disodium hydrogenphosphate $(0.014 \mathrm{~g})$, and ammonium chloride $(0.134 \mathrm{~g})$ were dissolved in the sample solution. The solution was made up to $5 \mathrm{~mL}$ with sample solution and allowed to stand for $15 \mathrm{~min}$. A sample of actual wastewater was measured by using the portable spectrophotometer with a light-emitting diode source and photodiode detector. The transmittance at $470 \mathrm{~nm}$ in the high sensitivity domain was measured for high boron concentrations.

\section{Portable spectrophotometer}

Boron was measured by using a portable spectrophotometer with LED (a light-emitting diode) source and photodiode detector. This device uses LED (470 nm) for light emitting section, photodiode $(370-600 \mathrm{~nm})$ for light receiving section. Measurement wavelength was adjusted $470 \mathrm{~nm}$ to prevent absorption of azomethine $\mathrm{H}$. 


\section{RESULTS AND DISCUSSION}

\section{Absorption spectra}

The absorption spectra of the boron-azomethine $\mathrm{H}$ complex and the corresponding reagent blank are shown in Fig. 1. The complex had an absorption peak at $413 \mathrm{~nm}$. In contrast to the blank reagent solution, there was no maximum absorption peak between 400 and $500 \mathrm{~nm}$. In order to achieve the highest sensitivity, a wavelength of $413 \mathrm{~nm}$ was selected for all the following experiments (Li et al., 2006).

\section{Effect of pH buffer solutions}

The boron-azomethine $\mathrm{H}$ complex was not formed in the buffer solution above $\mathrm{pH} 7$, and it formed slowly below $\mathrm{pH} 3$. For our method, $\mathrm{pH} 6$ was best suited for the formation of the boron-azomethine $\mathrm{H}$ complex. Figure 2 shows a comparison of the phosphate and acetate buffer solutions for the reaction rate. The formation of the boron-azomethine $\mathrm{H}$ complex took $2 \mathrm{~h}$ when the reagents were added according to the Japanese industrial standards (JIS); however, when ammonium acetate buffer solution was used, this time was shortened to $5 \mathrm{~min}$. The ammonium acetate buffer is used for well azomethine $\mathrm{H}$ method (Ozawa, 1986). The formation time when ammonium ions were added to the phosphate buffer solution was shorter than when acetate ions were added (Fig. 3). The ammonium ions facilitated the formation of the boron-azomethine $\mathrm{H}$ complex.

\section{Effect of ammonium ion concentration}

When the ammonium acetate concentration was less than $0.5 \mathrm{~mol} / \mathrm{L}$, the equilibrium time for the formation of the boron-azomethine H complex was long (Fig. 4), whereas when it was over $0.5 \mathrm{~mol} / \mathrm{L}$, the equilibrium time was the same as that for $0.5 \mathrm{~mol} / \mathrm{L}$. Therefore, the $0.5 \mathrm{~mol} / \mathrm{L}$ ammonium ion was best suited for the formation of the complex.

\section{Acceleration effect of various amine compounds}

Methylamine hydrochloride, dimethylamine hydrochloride, trimethylamine hydrochloride or tetramethylammonium chloride was added $(0.1 \mathrm{~mol} / \mathrm{L})$ instead of

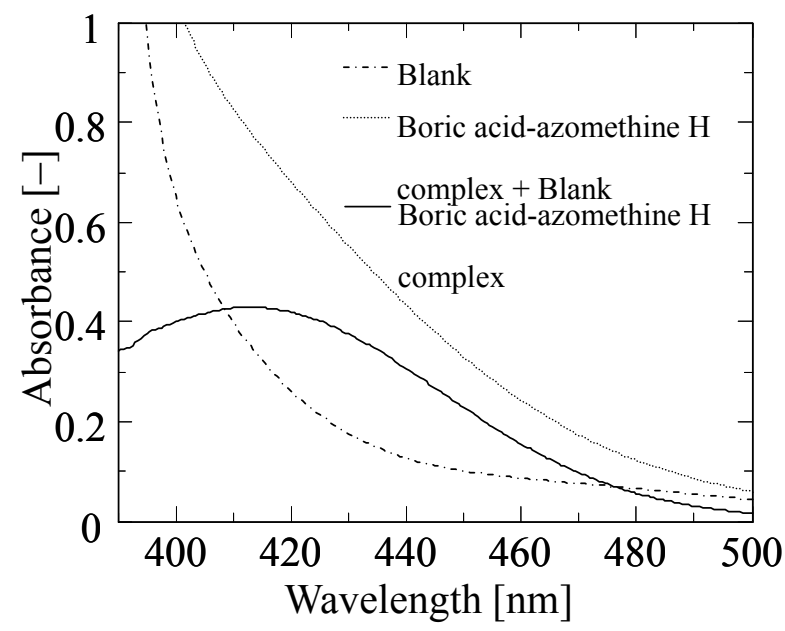

Fig. 1 - Absorption spectra of boron-azomethine $\mathrm{H}$ complex. (5 mmol/L azomethine $\mathrm{H} ; 0.54 \mathrm{mg} / \mathrm{L}$ boron; $\mathrm{pH}$ 6) 


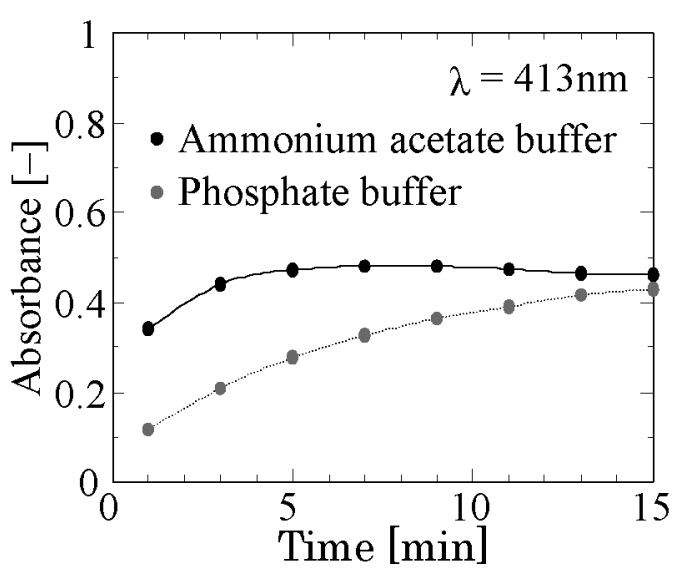

Fig. 2 - Comparison of reaction rate for the boron-azomethine $\mathrm{H}$ complex formation between ammonium acetate and phosphate buffers.

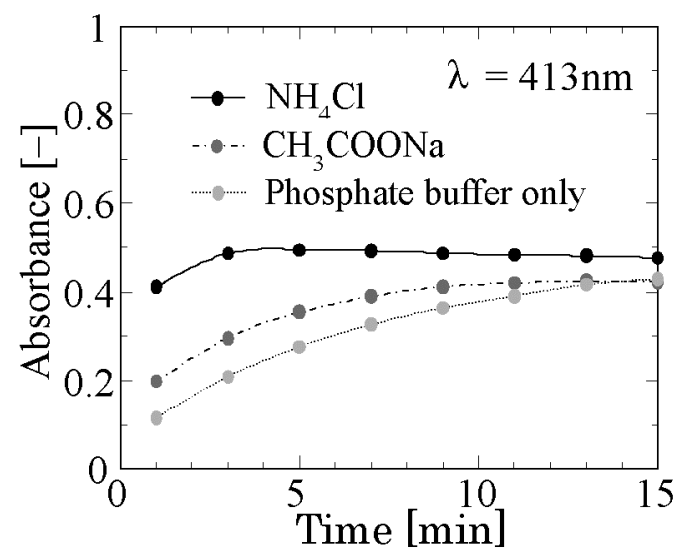

Fig. 3 - Acceleration effect of ammonium ion for the boron-azomethine H complex formation.

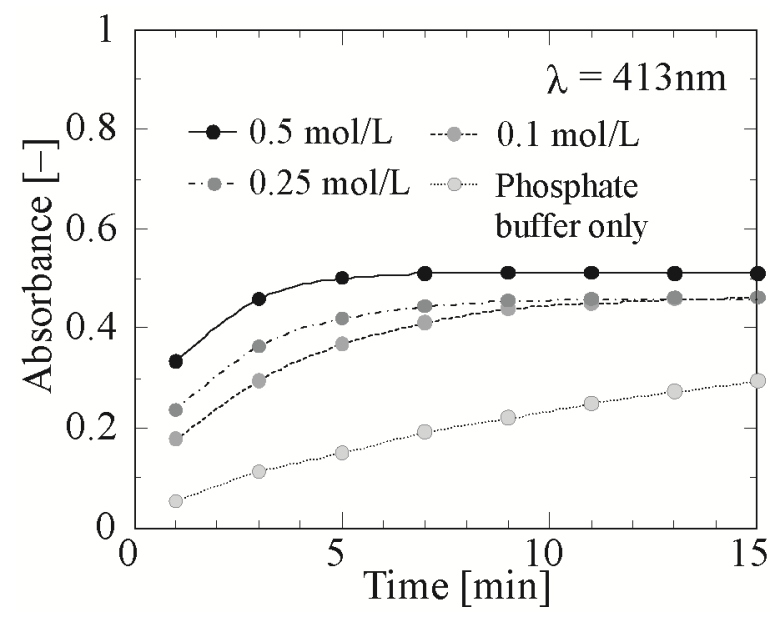

Fig. 4 - Effect of ammonium ion concentration for the formation of the boron-azomethine H complex.

ammonium ions to the phosphate buffer. All these compounds, except tetramethylammonium chloride, accelerated the formation of the boron-azomethine $\mathrm{H}$ complex (Fig. 5). The formation of the complex was slower for tetramethylammonium chloride than that for only the phosphate buffer. The initial rate $\left(v_{0}\right)$ was defined as the change in the concentration of the boron-azomethine $\mathrm{H}$ complex per unit time within the first minute (1),

$$
v_{0}[\mathrm{~mol} /(\mathrm{L} \cdot \min )]=\left.\frac{d[\mathrm{~B}-\mathrm{AmH}]}{d t}\right|_{\text {initial }} \approx \frac{\mathrm{A}_{1}}{\varepsilon \mathrm{l}}
$$

where $[\mathrm{B}-\mathrm{AmH}]$ is the concentration of the boron-azomethine $\mathrm{H}$ complex, $\mathrm{A}_{1}$ is the absorbance after $1 \mathrm{~min}, \varepsilon$ is molar absorption coefficient obtained from Method $1(\varepsilon=$ $9,500 \mathrm{~L} /(\mathrm{mol} \cdot \mathrm{cm})$ and 1 is light path length $(1 \mathrm{~cm})$. The initial rate $\left(v_{0}\right)$ was calculated with $\mathrm{A}_{1}, \varepsilon$ and 1 . 
Table 1 shows the $\mathrm{pKa}$ of onium ion and initial rates for each of the amine compounds and ammonia. The initial rates increased as the $\mathrm{pKa}$ decreased (Table 1).

When 4-methylpyridine or pyridine was added $(0.1 \mathrm{~mol} / \mathrm{L})$ to observe a promotion effect, the acceleration of the formation reaction was greater than that for the other amine compounds (Fig. 6). Furthermore, when the $\mathrm{pKa}$ of onium ion was near 6 , the initial rates were increased (Table 2). The methyl group in 4-methylpyridine increases the nucleophilicity of the nitrogen which facilitates the formation of the boron-azomethine $\mathrm{H}$ complex. However, the use of these compounds is not general for these toxicity, bad smell and handling with care.

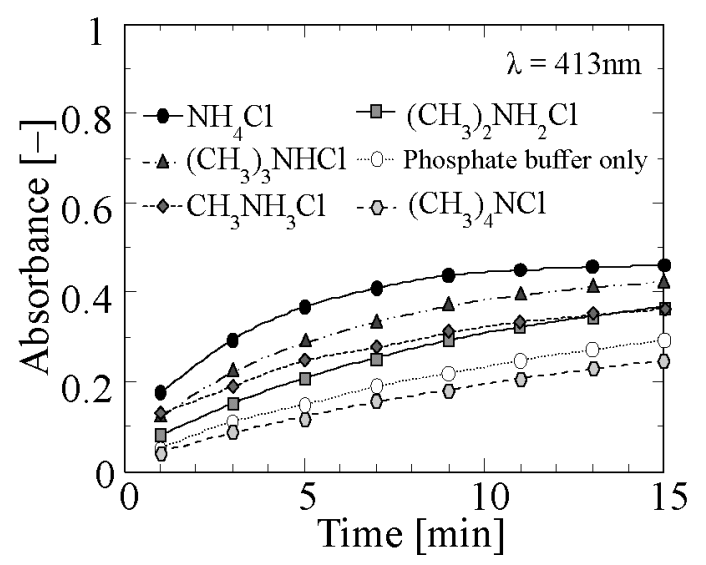

Fig. 5 - Acceleration effect of various amine compounds.

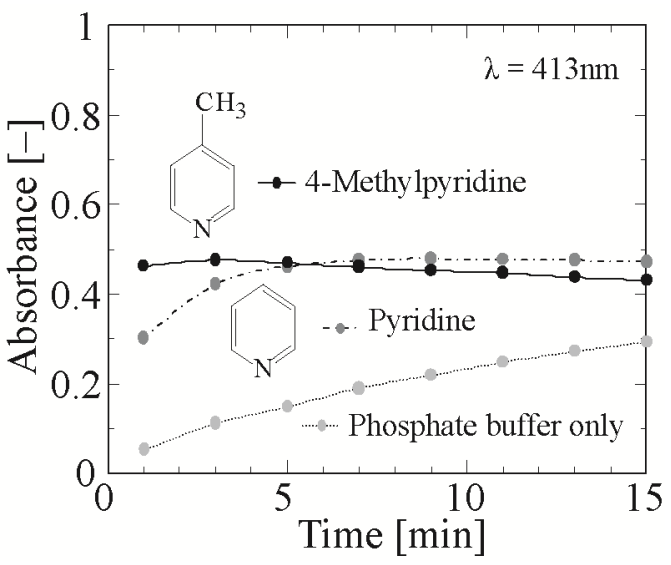

Fig. 6 - Acceleration effect of aromatic amines.

Table 1- $\mathrm{pKa}$ of amine compounds and initial rates.

\begin{tabular}{cccc}
\hline Compounds & $\begin{array}{c}\text { Chemical } \\
\text { formula }\end{array}$ & $\mathrm{pKa}$ of onium ion & $\begin{array}{c}\text { Initial rate } v_{0} \\
\left(10^{-5} \mathrm{~mol} /(\mathrm{L} \cdot \mathrm{min})\right)\end{array}$ \\
\hline Ammonia & $\mathrm{NH}_{3}$ & 9.26 & 1.9 \\
Trimethylamine & $\left(\mathrm{CH}_{3}\right)_{3} \mathrm{~N}$ & 9.81 & 1.3 \\
Methylamine & $\mathrm{CH}_{3} \mathrm{NH}_{2}$ & 10.66 & 1.4 \\
Dimethylamine & $\left(\mathrm{CH}_{3}\right)_{2} \mathrm{NH}$ & 10.73 & 0.86 \\
Tetramethylammonium & $\left(\mathrm{CH}_{3}\right)_{4} \mathrm{~N}$ & - & 0.47 \\
\hline
\end{tabular}


Table 2- $\mathrm{pKa}$ of the aromatic amines and initial rates.

\begin{tabular}{cccc}
\hline Compounds & Chemical formula & $\mathrm{pKa}$ of onium ion & $\begin{array}{c}\text { Initial rate } v_{0} \\
\left(10^{-5} \mathrm{~mol} /(\mathrm{L} \cdot \mathrm{min})\right)\end{array}$ \\
4-Methylpyridine & $\mathrm{C}_{3}$ & 5.6 & 4.9 \\
Pyridine & & 5.25 & 3.2 \\
\hline
\end{tabular}

\section{Mechanism of reaction}

The Schiff base is formed from the primary amine and the aldehyde by the nucleophilic attack of the free amine on the aldehyde; therefore salicylaldehyde condenses with $\mathrm{HA}^{2-}$ of the H-acid species to form azomethine $\mathrm{H}$ (Matsuo et al., 2004). The salicylaldehyde formed in acidic solution is denoted as HS. 4-Methylpyridine and pyridine accepted protons from $\mathrm{H}_{2} \mathrm{~A}^{-}$, formed by the protonated $\mathrm{H}$-acid and azomethine $\mathrm{H}$. Azomethine $\mathrm{H}$ was formed from the combination of $\mathrm{HS}$ and $\mathrm{HA}^{2-}$. HS react with $\mathrm{HA}^{2-}$ to form the intermediate, the intermediate was dehydrated to form azomethine H (Fig. 7). Therefore, the addition of the amine compounds allowed the formation of azomethine $\mathrm{H}$ from $\mathrm{HS}$ and $\mathrm{HA}^{2-}$, which then reacted with boric acid to form the boron-azomethine $\mathrm{H}$ complex.

\section{Powdered reagents for the azomethine $\mathrm{H}$ method}

When the azomethine $\mathrm{H}$ method was used for on-site boron analysis, all reagents were powdered for simplification of the procedure and stabilization of reagents. When the azomethine $\mathrm{H}$ concentration was increased, the absorption increased. Therefore, the high-sensitivity, quantitative determination of boron is possible. The best buffer as powder reagents was discussed. Ammonium acetate is a deliquescent powder; therefore ammonium chloride was used instead. Phosphate, phthalate, and MES buffer were compared with the acetate buffer. The boron-azomethine $\mathrm{H}$ complex absorption peak at $413 \mathrm{~nm}$ was large in the phthalate buffer, even though the hydroxyl group in the phthalate and MES buffer is supposed to inhibit the formation of the complex. Therefore, the combination of powdered azomethine H, L-ascorbic acid, EDTA, potassium dihydrogenphosphate, disodium hydrogenphosphate, and ammonium chloride was selected for our azomethine $\mathrm{H}$ method.

\section{Storage of powdered reagents}

The powdered reagents were stored as a mixture or separately, under atmospheric conditions or under vacuum, at room temperature or refrigerated, and under natural light or in the dark. The complex absorption peak at $413 \mathrm{~nm}$ decreased when the reagents were exposed to natural light or air, because the azomethine H degraded (Lohse, 1982). The absorbance was stable when the reagents were stored under vacuum and in the dark. Storage of the reagents as a mixture or separately made no difference. Therefore, the reagents were stored as a mixture, under vacuum and in the dark.

\section{Effect of foreign ions}

The presence of chloride ions at a concentration of 100 and $1,000 \mathrm{mg} / \mathrm{L}$, did not effects determination of boron with the powdered reagents (Table 3). Also the presence of 


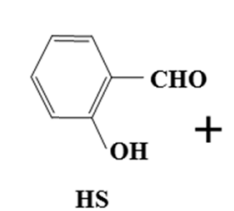

Salicylaldehyde
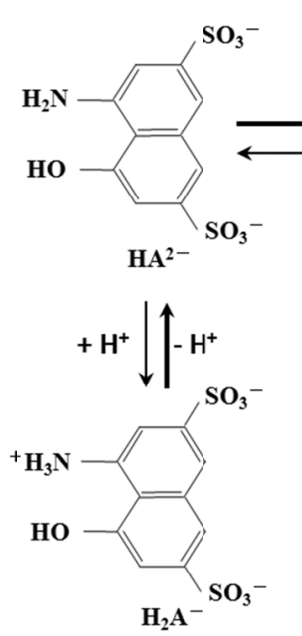

H-acid

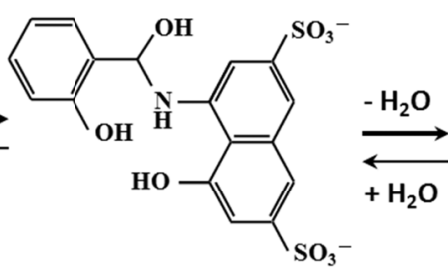

Intermediate<smiles>O=[S+]([O-])c1cc(N=Cc2ccccc2O)c2c(O)cc(S(=O)(=O)[O-])cc2c1</smiles>

Azomethine H

$\mathbf{B}(\mathbf{O H})_{3}$

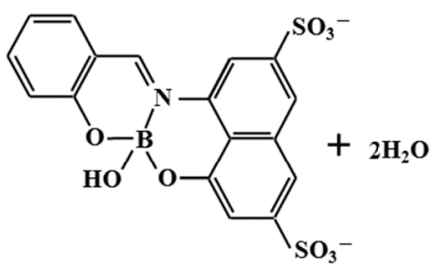

Boron-Azomethine H complex

Fig. 7 - The complexation of boron-azomethine $\mathrm{H}$ and formation of intermediates made from salicylaldehyde, $\mathrm{H}$-acid.

sulfate ions and nitrate ions at a concentration of $100 \mathrm{mg} / \mathrm{L}$ and fluoride ions at a concentration of $400 \mathrm{mg} / \mathrm{L}$ did not effects determination of boron with the same reagents. The boron-azomethine $\mathrm{H}$ complex was decreased by aluminum ions at a concentration of $100 \mathrm{mg} / \mathrm{L}$ and calcium ions at a concentration of $200 \mathrm{mg} / \mathrm{L}$. The decrease was probably caused by the formation of calcium phosphate and aluminum phosphate in the phosphate buffer (Madsen and Thorvardarson, 1984; Kumar et al., 2006). The problem was counteracted by doubling the volume of the phosphate buffer.

\section{Measurement of boron in real samples}

Using powdered reagents for the improved azomethine $\mathrm{H}$ method with conventional spectrophotometer was $0.1 \mathrm{mg} / \mathrm{L}$ of detection limit, and $0.2-1.5 \mathrm{mg} / \mathrm{L}$ dynamic range. The concentrations of boron in hot spring waters at four sampling spots (A, B, C and D) estimated by spectrophotometer with proposed Method 2 and ICP-MS (Elan DRCII, PerkinElmer Co., Ltd.) produced similar results (Table 4). The RSD of these results was $1.3-2.6 \%(\mathrm{~N}=5)$.

The boron standard curve from 0.5 to $10 \mathrm{mg} / \mathrm{L}$ and $0.3 \mathrm{mg} / \mathrm{L}$ of detection limit were constructed using powdered reagents for the improved azomethine $\mathrm{H}$ method with portable spectrophotometer. Real sample of hot spring wastewaters (E) and wastewater from optical glass company ( $\mathrm{F}$ and $\mathrm{G}$ ) was measured by a portable spectrophotometer with proposed Method 3. Table 5 shows the concentration of coexisting ions by ICP-MS analysis and ion chromatography in these real samples. Calcium and other ions were included in real sample, but the results of the boron concentrations were also similarly (Table 6). The RSD of these results was $1.0-2.6 \%(\mathrm{~N}=5)$. The portable spectrophotometer is useful for on-site determination of boron in hot spring and industrial wastewater. 
Table 3- Effect of foreign ions to boron determination by Method 2.

\begin{tabular}{|c|c|c|c|}
\hline Ion/compound & $\begin{array}{c}\text { Added foreign ion } \\
\text { concentration (mg/L) }\end{array}$ & $\begin{array}{c}\text { Measured boron } \\
\text { concentration }(\mathrm{mg} / \mathrm{L})\end{array}$ & $\mathrm{RSD}$ \\
\hline $\mathrm{Cl}^{-}$ & 100 & 0.82 & $2.6 \%$ \\
\hline & 1000 & 0.82 & $2.1 \%$ \\
\hline $\mathrm{SO}_{4}^{2-}$ & 100 & 0.83 & $2.4 \%$ \\
\hline $\mathrm{NO}_{3}^{-}$ & 100 & 0.84 & $0.6 \%$ \\
\hline $\mathrm{F}^{-}$ & 400 & 0.78 & $1.4 \%$ \\
\hline $\mathrm{Al}^{3+}$ & 100 & 0.35 & $2.3 \%$ \\
\hline $\mathrm{Al}^{3+2)}$ & 100 & 0.84 & $3.4 \%$ \\
\hline $\mathrm{Ca}^{2+}$ & 200 & 0.48 & $2.7 \%$ \\
\hline $\mathrm{Ca}^{2+2)}$ & 200 & 0.81 & $1.2 \%$ \\
\hline
\end{tabular}

1) Prepared boron concentration was $0.80 \mathrm{mg} / \mathrm{L}$.

2) Twice volume of the phosphate buffer was added.

Table 4 - The boron concentration in hot spring wastewaters by using proposed Method 2 and ICP-MS.

\begin{tabular}{|c|c|c|c|c|}
\hline Real sample & Method 2 $(\mathrm{mg} / \mathrm{L})$ & RSD & ICP-MS (mg/L) & RSD \\
\hline A & 2.4 & $2.5 \%$ & 2.4 & $0.3 \%$ \\
B & 1.0 & $1.3 \%$ & 0.9 & $0.2 \%$ \\
C & 0.7 & $2.0 \%$ & 0.7 & $1.4 \%$ \\
D & 2.9 & $2.6 \%$ & 3.1 & $0.4 \%$ \\
\hline
\end{tabular}

Table 5 - Chemical composition of hot spring wastewaters (E) and wastewater from optical glass company ( $F$ and $G)$.

\begin{tabular}{|c|c|c|c|}
\hline Element/ions & $\mathrm{E}(\mathrm{mg} / \mathrm{L})$ & $\mathrm{F}(\mathrm{mg} / \mathrm{L})$ & $\mathrm{G}(\mathrm{mg} / \mathrm{L})$ \\
\hline $\mathrm{B}$ & 62.5 & 93.2 & 45.7 \\
$\mathrm{Ca}$ & 370 & 50.9 & 46.4 \\
$\mathrm{Mg}$ & 130 & 4.9 & 3.5 \\
$\mathrm{Al}$ & 5.8 & 0.6 & 0.4 \\
$\mathrm{~F}^{-}$ & 17 & 7.5 & 1.9 \\
$\mathrm{NO}_{3}^{-}$ & 33 & 13.8 & 11.9 \\
$\mathrm{Cl}^{-}$ & 12000 & 610 & 544 \\
\hline
\end{tabular}


Table 6- The boron concentration in hot spring wastewaters (E) and wastewater from optical glass company ( $F$ and $G$ ) were measured by a portable spectrophotometer with proposed Method 3.

\begin{tabular}{|c|c|c|}
\hline Real sample & $\begin{array}{c}\text { Measured boron } \\
\text { concentration }(\mathrm{mg} / \mathrm{L})\end{array}$ & RSD \\
\hline $\mathrm{E}$ & 68 & $1.0 \%$ \\
$\mathrm{~F}$ & 98 & $2.6 \%$ \\
$\mathrm{G}$ & 50 & $2.3 \%$ \\
\hline
\end{tabular}

\section{CONCLUSIONS}

A $\mathrm{pH}$ of 6 was optimal for the formation of boron-azomethine $\mathrm{H}$ complex, and an absorbance of $413 \mathrm{~nm}$ was used to detect the complex. The formation time for the boron-azomethine $\mathrm{H}$ complex was shortened to $5 \mathrm{~min}$ when acetate buffer solution was used, and further shortened by the use of phosphate buffer solution containing ammonium ions. The ammonium ion facilitated the formation of the boron-azomethine $\mathrm{H}$ complex. The $0.5 \mathrm{~mol} / \mathrm{L}$ ammonium ion was best for the formation of the boron-azomethine $\mathrm{H}$ complex. Azomethine $\mathrm{H}$ was formed readily from the combination of salicylaldehyde and $\mathrm{H}$-acid when amine compounds were added. The boron-azomethine $\mathrm{H}$ complex was also formed from the combination of boric acid and azomethine $\mathrm{H}$.

Powdered azomethine H, L-ascorbic acid, EDTA, potassium dihydrogenphosphate, disodium hydrogenphosphate, and ammonium chloride were used as reagents for our azomethine $\mathrm{H}$ method. When the volume of the phosphate buffer was increased twofold, the presence of aluminum ions at a concentration of $100 \mathrm{mg} / \mathrm{L}$ and calcium ions at a concentration of $200 \mathrm{mg} / \mathrm{L}$ did not affect the intensity of the absorbance. The reagent powders were best stored under vacuum and in the dark. Our method is suitable for the simple, rapid, on-site determination of boron in wastewater on a portable spectrophotometer.

\section{REFERENCES}

Capelle K. (1961) Microdosage colorimétrique du bore en milieu aqueux, au moyen de réactifs a groupement azol̂que ou imine dérivés des acides h et k. Anal. Chim. Acta, 24, 555-572. (in French)

Cizek Z. and Studlarova V. (1984) Extraction-spectrophotometric determination of small amounts of boron in copper metal and copper-base alloys with methylene blue. Talanta, 31(7), 547-549.

Goldberg S. (1997) Reactions of boron with soils. Plant and Soil, 193(1-2), 35-48.

Hosoya M. and Takeuchi M. (1986) Determination of micro-amounts of boron in steel with 1-(salicylideneamino)-8-hydroxynaphthalene-3,6-disulfonic acid spectrophotometry after methyl borate distillation. Bunseki Kagaku, 35(10), 854-857. (in Japanese)

Howe P. D. (1998) A review of boron effects in the environment. Biol. Trace Elem. Res., 66(1-3), 153-166.

Kluczka J., Ciba J., Trojanowska J., Zolotajkin M., Turek M. and Dydo P. (2007) 
Removal of boron dissolved in water. American Institute of Chemical Engineers Environ. Prog., 26(1), 71-77.

Kumar V. S., Padmasri A. H., Satyanarayana C. V. V., Reddy I. A. K., Raju B. D. and Rao K. S. R. (2006) Nature and mode of addition of phosphate precursor in the synthesis of aluminum phosphate and its influence on methanol dehydration to dimethyl ether. Catal. Commun., 7(10), 745-751.

Li Z., Cui Z. and Tang J. (2006) The determination of boron in food and seed by spectrophotometry using a new reagent 3,4-dihydroxyazomethine-H. Food Chemistry, 94(2), 310-314.

Liu Y. M. and Lee K. (2009) Modifications of the curcumin method enabling precise and accurate measurement of seawater boron concentration. Marine Chemistry, 115(1-2), 110-117.

Lohse G. (1982) Microanalytical azomethine-H method for boron determination in plant tissue. Comm. Soil. Sci. Plant. Anal., 13(2), 127-134.

Madsen H. E. L. and Thorvardarson G. (1984) Precipitation of calcium phosphate from moderately acid solution. J. Cryst. Growth, 66(2), 369-376.

Matsuo H., Miyazaki Y., Takemura H., Matsuoka S., Sakashita H. and Yoshimura K. (2004) ${ }^{11} \mathrm{~B}$ NMR study on the interaction of boric acid with Azomethine $\mathrm{H}$. Polyhedron, 23(6), 955-961.

Morales G. V., Capretto M. E., Fuentes L. M. and Quiroga O. D. (2000) Dissolution kinetics of hydroboracite in water saturated with carbon dioxide. Hydrometallurgy, 58(2), 127-133.

Nable R. O., Banuelos G. S. and Paull J. G. (1997) Boron toxicity. Plant and Soil, 193(1-2), 181-198.

Ozawa T. (1986) Spectrophotometric determination of boron in glass with 1-(salicylideneamino)-8-hydroxynaphthalene-3,6-disulfonic acid. Bunseki Kagaku, 35(8), 709-712. (in Japanese)

Takeuchi M. and Takeyama S. (1983) Spectrophotometric determination of boron in steels and alloys with 1-(salicylideneamino)-8-hydroxynaphthalene-3,6-disulfonic acid. Bunseki Kagaku, 32(6), T66-T69. (in Japanese)

Zenki M., Nose K. and Toei K. (1989) Spectrophotometric determination of boron with an azomethine H derivative. Fresenius Z. Anal. Chem., 334(3), 238-241. 